\title{
RESTORING BALANCE IN PUBLIC FINANCE IN EUROPE IN THE LIGHT OF THE FISCAL COMPACT
}

\section{Abstract}

The aim of this article is to assess the extent to which Member States have achieved their medium-term budgetary objectives (MTOs) and the benchmark for government debt reduction in the light of the Fiscal Compact's provisions. It also identifies the risks involved in this process. By carrying out a statistical analysis and a review of the subject literature, the author shows that less than half of Member States have managed to meet the requirements imposed by the Fiscal Compact. The analysis suggests that the impact of fiscal consolidation on economic growth is seen as one of the main reasons for this state of affairs. The author regards the provisions of the Fiscal Compact as a welcome step towards anchoring fiscal discipline in Europe. If it is implemented and strictly enforced, they should strengthen the existing fiscal governance framework and foster its credibility in the future, substantially reducing the risk of another sovereign debt crisis.

Keywords: medium-term budgetary objective (MTO), debt-to-GDP ratio, fiscal consolidation, the Stability and Growth Pact, the Fiscal Compact.

JEL Classification: E61, E62.

\section{Introduction}

In the days before the outbreak of the Great Depression, when classical economics was still dominant, state budget policies were often related to family budgetary policy. As A. Smith said, what is prudence in the conduct of every private family can scarce be folly in that of a great kingdom (Smith 1954, p. 47). State financial responsibility was associated fundamentally

Piotr Ptak, Helena Chodkowska University of Technology and Economics in Warsaw, Chair of Economics and Finance, Jagiellońska 82F, 03-301 Warszawa, Poland, e-mail: pp2005@wp.pl 
with the determinants of family well-being. Saving was a virtue, which was reflected in the view that the state budget should, in the absence of a surplus, at least be balanced, and the deficit was allowed only in exceptional circumstances. Serious and persistent deficit was considered a sign of fiscal insanity (Buchanan, Burton \& Wagner 1978). Indeed, until the 1930s it was commonly believed that a balance between expenditures and state revenue is normal while the lack of a balance - a budget deficit - was abnormal (see Cossa 1884).

Balancing the budget was certainly a good rule of fiscal policy - it was simple and completely stanched the problem of overspending. Of course, its being good did not prevent governments running up debt. For example, the UK's debt in 1820 came in at 132\% of GDP (Rzońca 2008, p. 17). However, governments usually did not increase debt in good times. Public debt appeared during wars, when public spending rose dramatically or disaster - floods, pestilence, drought, and the like - struck, tanking tax revenue. Deficits were also caused by difficulties in creating an adequate revenue base for the growing need for expenditure amid civilization's rapid progress (Wernik 2011, p. 178). Despite the widespread recognition, the rule expressed in a balanced budget was broken in the 1930s. Economists began to see budget deficit as an instrument that could stimulate the economy in times of recession. The great English economist J. M. Keynes was among the leading proponents of using the deficit to this end, as were those who followed in his footsteps. However, he advocated increasing the deficit only in times of recession, because he was aware that during a cyclical recovery, which always takes place after the recession, higher public spending will drive up prices and crowd out private spending (Keynes 1985, p. 151). Hence, the budget should show a surplus when aggregate demand is excessive in relation to the state of full employment, which leads to economic imbalances. As economic history shows, Keynesian recommendations were roundly ignored.

Irresponsible fiscal policies pursued by governments in Europe before the crisis for purposes other than stabilising the economy constitute a good example of just how J. M. Keynes was ignored. Debt and deficit levels in many countries exceeded the acceptable limits, which were recorded in the Treaty on the Functioning of the European Union (TFUE) and in the Stability and Growth Pact (SGP) ${ }^{1}$. Further deepening of the fiscal imbalances, caused by the recent global financial crisis, led the most indebted countries to the very

1 In years 1999-2009, Member States violated the deficit rule 74 times and the debt rule 93 times. Indeed, the system of fiscal discipline adopted in the EU did not work. 
brink of bankruptcy. Exploding public debt together with the gradually ageing population has made clear the need to double down on fiscal discipline. Past mistakes, including a failure to balance public finance during periods of high economic growth (such as occurred during 2006-2007), are to be avoided, while the surplus should be a natural state, as Keynes himself advocated. He reiterated: "(...) The time for the Treasury to be severe is during a boom" (Skidelsky 2012, p. 161).

The financial and economic crisis, which became a sovereign debt crisis, forced European leaders to adopt solutions aimed at instilling sustainable fiscal discipline in Member States. In December 2011 a package of six legal acts strengthening economic governance in the EU was adopted. Known as the Six-Pack, it reforms the Stability and Growth Pact of 1997. The following year, $25^{2}$ Member States signed the Treaty on Stability, Coordination and Governance in the EMU (TSCG), the so-called Fiscal Compact. One of the main provisions of the Treaty calls for national governments to balance their budget or run a surplus. This rule refers to the annual structural balance of the general government at its country-specific medium-term budgetary objective (MTO) as defined in the revised Stability and Growth Pact. The reformed Stability and Growth Pact and the Fiscal Compact represent the foundations of a new European economic system of governance. The several years since the rules came into effect encourage an evaluation of the solutions adopted to determine whether balance has been restored to Europe's public finance.

The main aim of the article is to assess the extent to which Member States have achieved their medium-term budgetary objectives and the benchmark for government debt reduction in the light of the Fiscal Compact's provisions. It also identifies the risks involved in this process and presents recommendations from legislative acts reforming the Stability and Growth Pact and the Fiscal Compact, the principal objective of which is to more effectively safeguard against the risk of irresponsible fiscal policy. Finally, the article seeks to prove that the financial and economic crisis, and subsequent sovereign debt crisis, is the ultimate evidence of the need to maintain continued fiscal discipline.

Section 2 points to the persistence of debt phenomena and examples of irresponsible fiscal policy pursued by governments in Europe, notably prior to the recent crisis. Section 3 presents the institutional reforms introduced in Europe as a response to the causes of the crisis, while Section 4 gives

2 The United Kingdom and the Czech Republic did not sign the Treaty. 
the general overview of the medium-term budgetary objective at the core of the preventive arm of the Stability and Growth Pact (European Commission 2016b). Section 5 examines the performance of Member States to determine whether they have achieved their medium-term budgetary objectives and the benchmark for government debt reduction in the light of the provisions of the Fiscal Compact. This section also includes an analysis of debt sustainability, which seeks to illustrate the potential the most highly leveraged countries have for pulling themselves out of debt in various macroeconomic circumstances. The last section offers concluding statements.

The methodology is based on my own analysis and assessment using research and professional experience. A review of the literature, empirical research, analytical reports (foremost from the European Commission but also the OECD and IMF), data and statistical analysis all figured in the overall methodology. Based on this methodology, the analysis of debt sustainability, including two sensitivity scenarios was conducted. The analysis conducted illustrates the changes that must be made to the structural primary balance in order for the most indebted countries to pull themselves out of debt. Deductive and inductive methods, analysis and synthesis, and comparative analysis were all used to achieve the objectives of the paper. Using this wide variety of methods enables the conclusion that the impact of fiscal consolidation on economic growth is one of the main reasons that less than half of Member States achieve the requirements imposed by the Fiscal Compact.

\section{Persistence of Deficits}

Statistics confirm that governments throughout the world persistently operate in debt, while Keynes's recommendations have been ignored. Fiscal data from OECD countries indicate that 45 of the 46 years between 1970 and 2015 showed a budget deficit, while a budget surplus occurred only once in Europe between 1995 and 2016.

For a striking example of irresponsible fiscal policy pursued by governments in Europe for purposes other than stabilising the economy, we need look no further than the years before the financial and economic crisis that began in 2008. The debt and deficit levels in many countries exceeded the limits laid down as acceptable in both TFUE and the SGP.

Structural weaknesses in public finance were covered by very high budgetary revenues fostered by the business cycle in a favorable phase, and in some countries by transactions in the asset market, particularly real 
estate, driven by increased private sector debt. Such circumstances were not conducive to governmental reform efforts, which consisted in removing significant structural problems of public finance. They emerged with full force when the financial and economic crisis crushed budget revenues. In addition, the need to stimulate economies and support the financial sector during the world's biggest economic downturn since the Great Depression was so strong that many countries, including the richest, decided to introduce large-scale fiscal packages. As a result, the deficit-to-GDP and debt-to-GDP ratios both skyrocketed (see Figure 1).

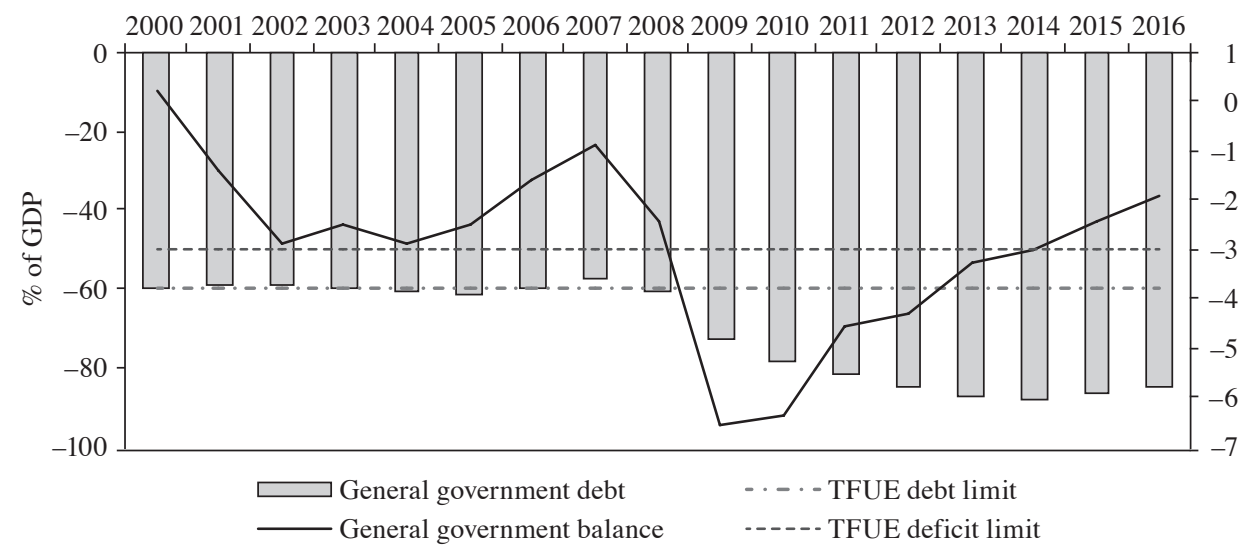

Fig. 1. General Government Debt and Deficit in Europe, 2000-2016, as a Percentage of GDP

Note: the right axis refers to general government balance; values are expressed as a percentage of GDP.

Source: AMECO database, European Commission.

The deepening fiscal imbalances caused by the crisis led the most indebted countries to the brink of bankruptcy. In the years 2008-2015, the debt-to-GDP ratio in Europe increased by no less than 26 percentage points. It was only fiscal consolidation undertaken by governments which gradually slowed the growth of debt relative to GDP. By 2015, the debt-to-GDP ratio was set on a downward path. 


\section{Institutional Reforms in Europe}

The Stability and Growth Pact of 1997 lays down the fiscal criteria to which all Member States are bound. $-3 \%$ of GDP is the threshold for the annual nominal balance of the planned or real general government sector. If a Member State exceeds that level, the European Council can, at the behest of the EC, threaten to impose the Excessive Deficit Procedure (EDP). Excessive deficit should be corrected in the year following its identification unless exceptional circumstances occur. In addition to the deficit criterion, there is also the general government debt criterion, which states that the general government debt should not exceed $60 \%$ of GDP. The financial and economic crisis turned sovereign debt crisis forced European leaders to adopt solutions aimed at establishing sustainable fiscal discipline in the Member States. In January 2012 a package of six legal acts (one directive and five regulations) strengthening economic governance in the EU came into force. This Six-Pack reforms the Stability and Growth Pact of 1997, setting down requirements for budgetary frameworks and indicating that Member States should have fiscal rules with clearly defined objectives and with mechanisms for effective and timely monitoring. It recommends that the fiscal rules should relate to the deficit and debt calculated according to EU-sanctioned methodology and relate to the entire general government sector. Member States should also set escape clauses and establish consequences for non-compliance. By applying rules in the annual budgetary process and in multi-annual budget planning, the Member States are to avoid pursuing pro-cyclical fiscal policies.

The provisions of the Six-Pack were grounded in the Treaty on Stability, Coordination and Governance in the EMU agreed in March 2012 at the European Union Summit. The Treaty specifies requirements for fiscal rules in the countries that are subject to the Treaty. The provisions oblige signatory States to introduce fiscal rules into national law in the form of legally binding and permanent norms set forth either in the Constitution or in any other form that guarantees their compliance. The two main elements of the Fiscal Compact are the mandatory balanced budget rule ${ }^{3}$ and the benchmark for government debt reduction.

3 The medium-term budget balance rule has been in force since 1998 under the Stability and Growth Pact, which states that the lower limit of the structural budget balance must be between $1 \%$ and $0 \%$ of GDP. This means that the Fiscal Compact's requirement to reduce the structural deficit to $0.5 \%$ of GDP does not bring anything new in practice, particularly given that in Member States with low debt the deficit can be increased up to $1 \%$ of GDP. However, this rule was not followed. 


\section{Mandatory Balanced Budget Rule}

The signatory Member States commit themselves to implement in their legislation a fiscal rule which requires that the general government budget be balanced or show a surplus. The fiscal rule is considered to have been respected if the annual structural balance meets the country-specific medium-term budgetary objective and does not exceed a deficit (in structural terms) of $0.5 \%$ of GDP. If the government debt ratio is significantly below $60 \%$ of GDP and risks to long-term fiscal sustainability are low, the medium-term budgetary objective can be set as low as a structural deficit of at most $1 \%$ of GDP. In the event that the structural balance of a country deviates significantly from the medium-term budgetary objective or the adjustment path towards it, a mechanism will be automatically triggered to correct these deviations.

\section{Benchmark for Government Debt Reduction}

The Fiscal Compact includes the numerical benchmark for debt reduction for Member States with government debt exceeding the $60 \%$ of GDP reference value, as foreseen in the reinforced Stability and Growth Pact. A Member State with general government debt above $60 \%$ of GDP is obliged to reduce the "surplus of debt" (that is, debt above 60\% of GDP) by one-twentieth annually. Countries that do not adhere to those rules may be subject to fines up to $0.1 \%$ of GDP.

The reformed Stability and Growth Pact and the Fiscal Compact represent the foundations of a new European system of economic governance. New regulations should substantially boost the chances of changing the irresponsible fiscal policies pursued by governments before the recent crisis.

\section{Medium-term Budgetary Objective - General Overview}

One of the basic instruments for coordinating the fiscal policies of the countries belonging to the Economic and Monetary Union, as defined in the Maastricht Treaty, is the condition that the general government deficit not exceed 3\% of GDP. The practice has shown, however, that in many countries satisfying this criterion proved elusive, especially in times of economic slowdown. Consequently, Member States in the Stability and Growth Pact have committed themselves to achieving and respecting the medium-term budgetary objective, which (European Commission 2016a, p. 17):

(i) provides a safety margin with respect to the 3\% of GDP deficit limit. For each Member State this safety margin is estimated in the form of a minimum 
benchmark that takes into account past output volatility and the budgetary sensitivity to output fluctuations;

(ii) ensures sustainability or rapid progress towards sustainability. This is assessed against the need to ensure the convergence of debt ratios towards prudent levels with due consideration to the economic and budgetary impact of ageing populations;

(iii) in compliance with (i) and (ii), allows room for budgetary maneuvering, in particular taking into account the needs for public investment.

The medium-term budgetary objective is at the core of the preventive arm of the Stability and Growth Pact. The budgetary targets are set in structural terms, i.e. cyclically adjusted and net of one-off and other temporary measures to ensure that the underlying fiscal position of Member States is conducive to medium-term sustainability, while allowing for the free operation of the automatic stabilizers.

To set an MTO, a safety margin is first calculated for each Member State. The cyclical part of the budget is estimated by multiplying the output gap that would have been observed during very low economic growth by an average sensitivity of the nominal general government balance to cyclical fluctuations (Mourre et al. 2013, pp. 6-10). Subsequently, the absolute value of the cyclical portion is subtracted from the number $3^{4}$, resulting in a structural balance (European Commission 2016, pp. 26-31).

The European Commission provides lower bound (minimum) MTOs, taking into account Member States' respective debt levels, the country-specific sustainability challenge posed by the costs of the ageing population and the specific dynamics of the automatic stabilizers every three years. In addition, countries undertaking structural reforms with a major impact on the sustainability of the public finances can also have their minimum MTOs revised on a case-by-case basis, in agreement with the European Commission. In particular, carrying out a major pension reform, which has an impact on long-term fiscal sustainability, could result in a revision of the minimum MTO. Euro area and ERM2 Member States must have an MTO that corresponds to at least $-1 \%$ of GDP. In addition to the requirements set by the minimum MTOs, the signatories to the Treaty on Stability, Coordination and Governance in the Economic and Monetary Union in EMU, namely all euro area Member States plus Bulgaria, Denmark and Romania, have further committed themselves to MTOs of at least $-0.5 \%$ of

\footnotetext{
${ }^{4}$ From $3 \%$ of the reference value of general government balance in relation to GDP.
} 
GDP, unless their debt ratio is significantly below $60 \%$ of GDP and the risks in terms of the long-term sustainability of their public finances are low.

As part of the assessment of the adjustment path, the EU Council and the Commission examine whether the country is implementing the annual adjustment of the structural balance required to achieve the MTO, accounting for $0.5 \%$ of GDP for euro area countries and countries participating in ERM II as a benchmark for this adjustment. For all Member States with debt levels in excess of $60 \%$ of GDP or with significant long-term debt service risk, the Council and the Commission examine whether the annual adjustment of the structural balance exceeds $0.5 \%$ of GDP. Correction should be higher in good times and lower in bad times.

From a theoretical point of view, the structural balance rule is a useful tool in limiting fiscal discretion. Basing the rule on the structural balance requires isolating from the nominal balance a value representing the hypothetical balance, assuming no cyclical and one-off factors (Hers \& Suyker 2014, p. 8). Since cyclical factors are considered as independent of the government and one-off factors in their nature do not affect the shape of long-term fiscal policy, the structural balance is that part of the nominal balance that is under government control. It is assumed that the structural balance reflects the fiscal policy conducted and changes in this category should, in principle, result from discretionary government action (Bedgoni \& Meaney 2017, p. 4). Another advantage of using the structural balance is that it provides the motivation to adopt a medium-term perspective when planning fiscal policy. This approach, in turn, gives the policy greater anti-cyclicality by virtue of the automatic stabilizers, since the rule based on structural balance (when the output gap is positive) automatically forces a more restrictive policy and, in the long run, allows for a more expansive one than would be the case if the rule was based on the nominal balance.

It is important that the value of the MTO for the vast majority of Member States was set below zero. The zero target of the structural balance would be too ambitious for countries whose economies have strived to merely hit the EU average ${ }^{5}$. Until this level is reached, GDP growth is expected to be higher than the European average. At the same time it can be shown that, in the long run, public debt in relation to GDP roughly converges to the ratio of the nominal fiscal deficit expressed in percentage of GDP and the nominal GDP growth rate (Wernik 2011, p. 118). For example, with a deficit maintained

5 For more on the disadvantages of using a structural budget balance as rule in fiscal policy, see e.g. (Kuusi 2017). 
at $1 \%$ of GDP and with a nominal GDP growth rate at $3 \%$, the debt would go down to $33 \%$ of GDP (assuming stable relation of deficit to GDP and nominal GDP growth). This means that a country whose GDP grows faster can reach correspondingly higher deficits and still maintain a debt-to-GDP ratio at the same level as a country with lower GDP growth.

\section{Implementation of the Fiscal Compact}

\subsection{The Mandatory Balanced Budget Rule - Performance}

For the years 2010-2016, the scale of the average fiscal adjustment in Europe should be considered high. The general government deficit was reduced on average by $4.5 \mathrm{pp}$ (from $6.4 \%$ to $1.9 \%$ of GDP); however, the debt-to-GDP ratio increased by $6.6 \mathrm{pp}$ and has been put on the downward path only since 2015 . However, continued deficit reduction and stabilisation at a level consistent with the medium-term budgetary objective proved to be a challenge for most Member States. Figure 2 demonstrates the level of structural balance achieved in 2016 against required MTOs established for Member States in 2016. In total, eleven Member States met their MTOs.

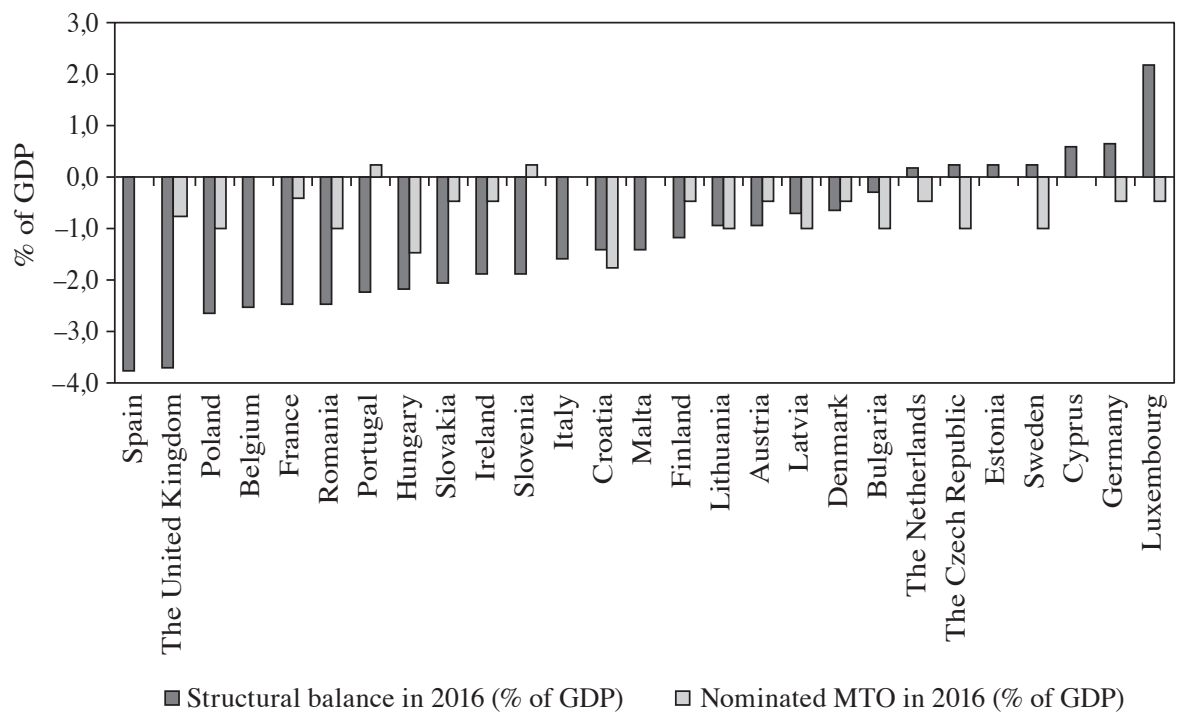

Fig. 2. Structural Balance against Medium-term Budgetary Objectives in 2016 in Europe

Source: AMECO database, European Commission. 
Restoring budget balance in recent years likewise proved to be a difficult task, due mainly to weak growth prospects. These weak prospects were related, first, to high private and public sector debt and the need to reduce it and, second, to the persistently high unemployment and uncertainty vis-a-vis the further development of the labor market. On the other hand, efforts to accelerate economic growth with fiscal stimulus were limited by the high debt levels and consolidation efforts undertaken by the most leveraged countries.

In general, changes in fiscal policy have two main effects on the economy: they directly affect aggregate demand, and they impact trust and expectations about the future (see Rosati 2013, pp. 30-35). Over the first three years of fiscal consolidation, Member States tightened fiscal policy, assuming that the second effect would overlap the first. However, since 2014 there has been a change in direction. Even though many Member States are far from stabilising their debt-to-GDP ratio, the scale of fiscal savings has been limited. Figure 3 illustrates this clearly.

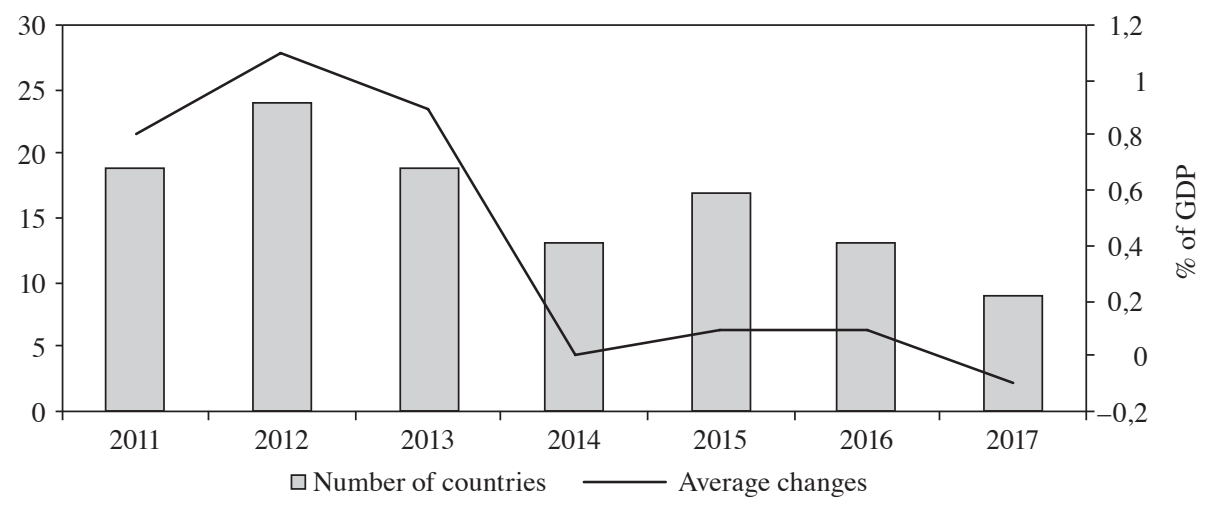

Fig. 3. Number of Countries Improving Their Structural Balance and Average Changes in Structural Balance as a Percentage of GDP in Europe

Note: the right axis refers to the average changes in structural balance as a percentage of GDP in Europe.

Source: AMECO database; the forecast for 2017 based on European Commission (2017).

Since 2014 noticeably fewer countries have managed to improve their structural balance, which is the key variable for assessing fiscal standing in the light of the Stability and Growth Pact and the Fiscal Compact. As a result, the scale of fiscal consolidation in structural terms has been considerably reduced as well. Furthermore, based on the most up-to-date European Commission forecast (European Commission 2017), the year 2017 will be 


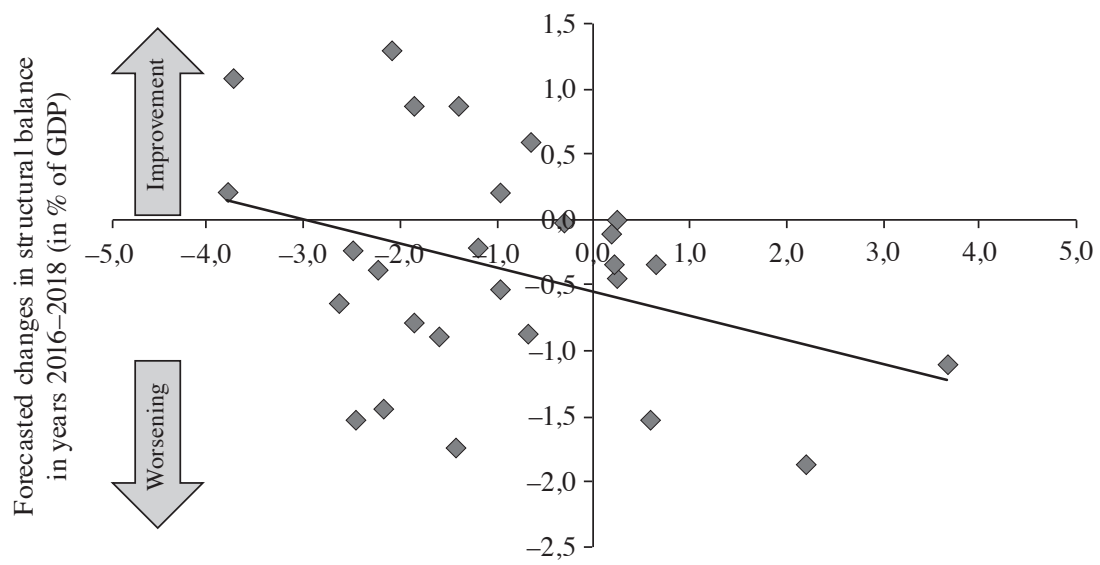

Structural balance in 2016 (in \% of GDP)

Fig. 4. Changes in Structural Balance in the Years 2016-2018 as a Percentage of GDP in Europe

Source: AMECO database and European Commission (2017).

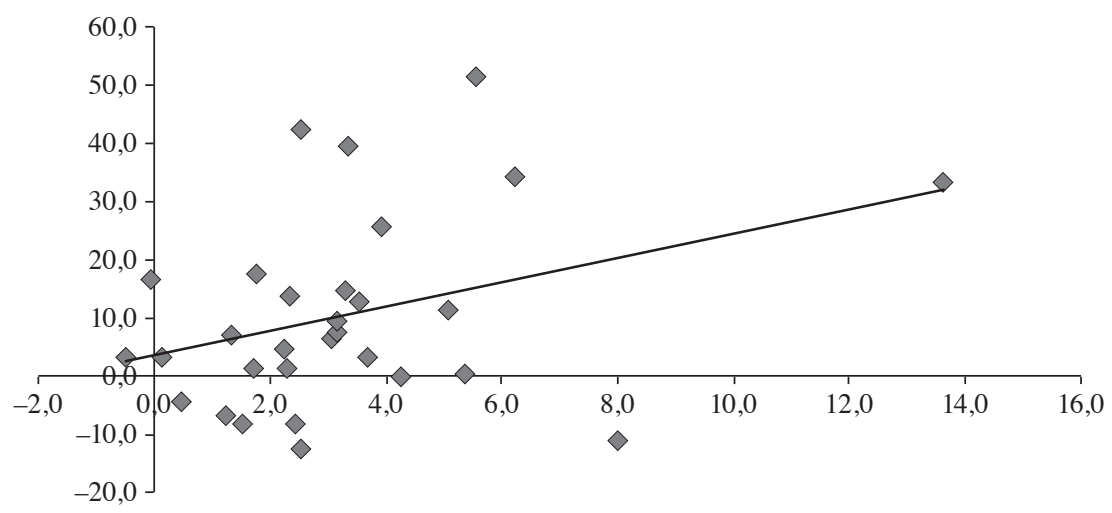

Fig. 5. Changes in Structural Balance and in Debt-to-GDP Ratio in the Years 2010-2016 as a Percentage of GDP in Europe

Note: the vertical axis refers to changes in the debt-to-GDP ratio; values in percentage of GDP.

Source: AMECO database, European Commission.

the first to see the structural balance worsen. In turn, Figure 4 shows the same forecast, according to which in the years 2016-2018, Europe as a whole will not improve its structural balance but actually worsen it. The structural balance is expected to improve in only eight countries. 
Figure 5 demonstrates the reason for the change in fiscal policy in recent years: countries with the highest fiscal savings in structural terms have experienced on average the highest increase in debt-to-GDP ratio in Europe.

Certainly, the relationship between these variables may suggest that savings so drastically suppress the demand that the resulting effect of low economic growth prevents further reduction of the debt. Savings are halted as the largest and most indebted euro area countries (France, Italy and Spain ${ }^{6}$ ) have not moved to stabilise their debts (see Table 1: Current scenario).

\subsection{Benchmark for Government Debt Reduction - Performance}

While there is no formula for breaking down changes in the debt ratio into underlying factors such as interest rates, inflation, fiscal adjustment, among others, the following equation comes close (Escolano 2010, p. 6):

$$
d_{t}-d_{t-1}=\frac{i_{t}}{1+y_{t}} d_{t-1}-\frac{y_{t}}{1+y_{t}} d_{t-1}+p_{t},
$$

where:

$d_{t}-$ debt at the end of period $t$, as a ratio to GDP at $t$.

$d_{t-1}-$ debt at the end of period $t-1$, as a ratio to GDP at $t-1$.

$i_{t}$ - nominal interest rate in period $t$; paid in period $t$ on the debt stock outstanding at the end of $t-1$.

$y_{t}$ - nominal GDP growth rate between $t-1$ and $t$.

$p_{t}$ - primary fiscal deficit ${ }^{7}$ in period $t$, as a ratio to GDP at $t$.

This equation indicates that the change in the debt ratio equals the impact of interest (positive) and nominal GDP growth (negative), plus the contribution of the primary deficit. After simplification ${ }^{8}$ :

$$
d_{t}-d_{t-1}=p_{t}+d_{t-1}\left[\frac{i_{t}-y_{t}}{1+y_{t}}\right] \text {. }
$$

Equation (2) shows that the change in the debt-to-GDP ratio is the sum of primary fiscal deficit and the snowball effect, which expresses the combined effect of the interest rate of government bonds and the growth rate of the nominal GDP in the debt-to-GDP ratio. If a constant debt-to-GDP ratio is

${ }^{6}$ In terms of the size of GDP, France, Italy and Spain are, respectively, the third, fourth and fifth largest European economies.

${ }^{7}$ In this equation the primary balance is expressed in structural terms.

${ }^{8}$ It was assumed that the impact of the stock-flow adjustment factor equals zero in this equation. 
to be maintained, the left side of equation (2) must equal zero. The condition for stabilising the debt-to-GDP ratio at a specified debt level is ensuring that:

$$
-p_{t}=d_{t-1}\left[\frac{i_{t}-y_{t}}{1+y_{t}}\right] .
$$

Equation (3) indicates that the condition for stability of the debt-to-GDP ratio requires that the relation of the primary deficit to GDP equals the snowball effect. Indeed, the public debt does not grow, if the primary deficit is compensated by the surplus of growth of nominal GDP above the average nominal interest of debt. In other words, the debt ratio will increase indefinitely if the nominal interest rate exceeds the growth rate of nominal GDP, unless the primary budget is in sufficient surplus to compensate for that (Bohn 2005, p. 7). This is the case many European countries are experiencing now. Hence, a sign of expression $\left(i_{t}-y_{t}\right)$ is crucial for the debt dynamic.

According to equation (3), the value of structural primary balance needs to equal its right side in order to stabilise the debt-to-GDP ratio. However, with a high and positive value of expression $\left(i_{t}-y_{t}\right)$, stabilising the debt-to-GDP ratio means that a primary balance must be maintained along with a sufficient primary surplus. Currently, France, Italy and Spain continue striving to achieve a structural primary balance and their medium-term budgetary objectives. In this respect, in the years 2010-2016, progress was somewhat evident, the fruit of fiscal consolidation, though the value of the structural primary deficit is still not sufficient to start decreasing the debt-to-GDP ratio. Apart from the current situation, Table 1 presents the sustainability of general government debt in France, Italy and Spain including two sensitivity scenarios intended to better illustrate the changes in relation to the required level of structural primary balance in accordance with equation (3).

Scenario 1 assumes lower inflation and real GDP rates by $1.0 \mathrm{pp}$ compared to 2017 forecast. In this case, the value of the primary balance beyond which the debt starts to fall increases significantly, meaning France and Italy will both require a structural primary surplus. In turn, Scenario 2 assumes higher inflation and real GDP rates by 1.0 pp compared to 2017 forecast. In this case, the value of the primary balance beyond which the debt starts to fall decreases considerably, allowing even for some relaxation in the fiscal policy stance. The analysis in Table 1 only confirms that the sign and value of structural primary balance in accordance with equation (3) is highly sensitive about the sign and value of expression $\left(i_{t}-y_{t}\right)$. At present, the low nominal GDP growth $\left(y_{t}\right)$, as it affects the rate of increase or decrease of the debt, makes reducing debt difficult. On the other hand, the European Central 
Bank's highly expansive monetary policy enables interest rates $\left(i_{t}\right)$ to be kept very low, thus keeping the cost of servicing debt low as well.

Table 1. Sustainability of General Government Debt in France, Italy and Spain

\begin{tabular}{l|c|c|c|c|c}
\hline \multirow{2}{*}{ Country } & \multicolumn{2}{|c|}{$\begin{array}{c}\text { Structural primary balance } \\
\text { as a percentage of GDP }\end{array}$} & \multicolumn{3}{|c}{$\begin{array}{c}\text { Threshold of structural primary balance } \\
\text { beyond which the debt starts to fall } \\
\text { (\% of GD) }\end{array}$} \\
\cline { 2 - 6 } & 2010 & 2016 & $\begin{array}{c}\text { Current } \\
\text { scenario }\end{array}$ & Scenario $1^{* *}$ & Scenario 2** \\
\hline France & $-5,8$ & $-2,5$ & $-1,4$ & 0,2 & $-3,6$ \\
\hline Italy & $-3,4$ & $-1,6$ & $-0,3$ & 2,3 & $-3,0$ \\
\hline Spain & $-7,1$ & $-3,8$ & $-2,2$ & $-0,3$ & $-4,1$ \\
\hline
\end{tabular}

"Level of debt since 2015 and long-term interest since 2016. ${ }^{* *}$ Scenario 1 reflects lower inflation and real GDP rates by $1.0 \mathrm{pp}$ compared to 2017 forecast (European Commission 2017). ${ }^{* * *}$ Scenario 2 reflects higher inflation and real GDP rates by 1.0 pp compared to 2017 forecast (European Commission 2017).

Source: the author's own calculations based on AMECO database and European Commission (2017).

In turn, the progress towards the second main element of the Treaty on Stability, Coordination and Governance in EMU, the benchmark for government debt reduction has also not been in line with the Fiscal Compact's provision. This means that the difference between the government debt-to-GDP ratio and $60 \%$ of GDP needs to be reduced at an average rate of one-twentieth per year. Table 2 demonstrates two paths to developing the debt-to-GDP ratio: the actual one and the one required by the Fiscal Compact.

Table 2. Changes of the Debt-to-GDP Ratio in Europe in the Years 2014-2016 (in Percentage of GDP)

\begin{tabular}{|c|c|c|c|c|c|c|c|}
\hline \multirow[t]{2}{*}{ Countries } & \multirow{2}{*}{$\begin{array}{c}\begin{array}{c}\text { Debt-to- } \\
\text {-GDP- } \\
\text {-ratio } \\
\text { (base year) }\end{array} \\
2013\end{array}$} & \multicolumn{3}{|c|}{$\begin{array}{l}\text { Changes of debt-to-GDP ratio } \\
\text { required by Fiscal Compact }\end{array}$} & \multicolumn{3}{|c|}{$\begin{array}{l}\text { Actual changes } \\
\text { of debt-to-GDP ratio }\end{array}$} \\
\hline & & 2014 & 2015 & 2016 & 2014 & 2015 & 2016 \\
\hline Spain & 95.4 & 93.6 & 91.9 & 90.3 & 100.4 & 99.8 & 99.7 \\
\hline France & 92.3 & 90.7 & 89.2 & 87.7 & 95.3 & 96.2 & 96.4 \\
\hline Italy & 129.0 & 125.6 & 122.3 & 119.2 & 131.9 & 132.3 & 132.8 \\
\hline
\end{tabular}

Source: the author's own calculations based on AMECO database and European Commission (2017). 
Since the adoption of the Fiscal Compact, only Spain has managed to reduce - and slightly at that - its debt-to-GDP ratio, while France and Italy have allowed it to continue to rise. If these countries had respected the provisions of the Treaty, the debt ratio would now amount to, on average, $10 \mathrm{pp}$ less than it does. Overall, in 2012-2016, fewer than half of Member States managed to reduce their debt.

Following the financial crisis, the European Commission demanded that the Member States take vigorous corrective measures as a response to the outbreak of the financial crisis, which nonetheless turned into a sovereign debt crisis. Furthermore, both the Stability and Growth Pact and the Fiscal Compact provide for penalties for breaking the rules. However, concerns about slowing economic growth led EU institutions to forego using these tools. Countries with budgetary problems including France, Portugal, Italy and Spain have several times been allowed to put off introducing corrective measures. This is due to fears that stronger fiscal tightening would lead in countries whose economy have been at the edge of recession for years, to both another economic slowdown and a heightened level of radical sentiment. A change in the attitudes of the European Union's authorities to fiscal problems can be seen in the draft of the European Parliament's Implementation of the Stability and Growth Pact of February 2017 (Angerer \& Japunčić 2017) on the basis of decisions and recommendations of the European Commission. There is no announcement of taking action to discipline countries that do not fulfill the objectives, and even countries where debt levels have been growing deserve a positive rating.

\section{Conclusions}

Using rules to constrain fiscal policy is nothing new in Europe's system of economic governance. The Stability and Growth Pact of 1997 included permissible limits on general government deficit and debt, but they were frequently violated. The adoption of the reformed Stability and Growth Pact and the Fiscal Compact is intended to put a permanent end to this practice. The solutions adopted should avoid duplication of past mistakes, including the failure to reach the medium-term budgetary objective during periods of high economic growth (such as in the years 2006-2007) and a failure to treat a budget surplus as a natural state.

These several years since the rules came into effect demonstrate that the process of restoring balance in public finance in Europe has been relatively slow. Less than half of Member States have managed to meet the 
requirements imposed by the Fiscal Compact, both in terms of achieving their MTOs and the benchmark of debt reduction. One reason for this failure is due to the impact of fiscal consolidation on economic growth. Drastic austerity measures have suppressed the aggregate demand while the resulting effect of low economic growth prevents further reductions to general government debt.

Compelled by fears that stronger fiscal tightening would lead, in countries whose economies have been on the edge of recession for years, to both another economic slowdown and a heightened level of radical sentiment, EU institutions have several times put off introducing needed corrective measures resulting from the Fiscal Compact. Note, however, that the halt to savings has taken place as the largest and most indebted euro area countries (France, Italy and Spain) have done little to stabilise their debt. The analysis conducted in this article confirms that.

Nevertheless, the Fiscal Compact was a welcome step towards anchoring fiscal discipline in the euro area and those non-euro area signatories that have declared themselves bound by the provisions of the Fiscal Compact (Denmark, Bulgaria and Romania). If strictly implemented and enforced, the fiscal compact should strengthen the existing fiscal governance framework and foster its credibility in the future. On the other hand, the resolutions enacted are nothing more than an attempt to return to the unspoken principle of a balanced budget and to treat the public finance deficit as at most temporary, and certainly not a normal state. Such was the case since the Great Depression until the outbreak of the financial crisis in 2008, which later turned into a sovereign debt crisis. Ultimately, the adoption of these solutions is an attempt to return to a state of sustained fiscal discipline.

\section{Bibliography}

Angerer, J. and Japunčić, T. (2017) Implementation of the Stability and Growth Pact. Briefing. Brussels: European Parliament.

Bedgoni, J. and Meaney, K. (2017) EU Fiscal Rules and International Expenditure Rules. Dublin: Irish Government Economic and Evaluation Service.

Bohn, H. (2005) The Sustainability of Fiscal Policy in the United States. CESifo Working Paper No. 1446. Munich: CESifo.

Buchanan, J. M., Burton, J. and Wagner, R. E. (1978) The Consequences of Mr. Keynes. Hobart Paper No. 78. London: Institute of Economic Affairs.

Cossa, L. (1884) Poczatki nauki finansów [The beginnings of finance science]. Warszawa: E. Wende i Spółka. 
Escolano, J. (2010) A Practical Guide to Public Debt Dynamics, Fiscal Sustainability, and Cyclical Adjustment of Budgetary Aggregates. Washington, DC: International Monetary Fund.

European Commission (2016a) Report on Public Finances in EMU. Institutional Paper 045, December. Luxembourg: Publications Office of the European Union.

European Commission (2016b) Vade Mecum on the Stability and Growth Pact. Institutional Paper 021, March. Luxembourg: Publications Office of the European Union.

European Commission (2017) European Economic Forecast - Winter 2017. Institutional Paper 048, February. Luxembourg: Publications Office of the European Union.

Hers, J. and Suyker, W. (2014) Structural Budget Balance. A Love at First Sight Turned Sour. CPB Policy Brief No. 7. The Hague: CPB Netherlands Burreau for Economic Policy Analysis.

Keynes, J. M. (1985) Ogólna teoria zatrudnienia, procentu i pieniądza [The theory of employment, interests and money]. Warszawa: PWN.

Kuusi, T. (2017) "Does the Structural Budget Balance Guide Fiscal Policy Pro-cyclically? Evidence from the Finnish Great Depression of the 1990s". National Institute Economic Review 239 (1): R14-R31, https://doi.org/10.1177/002795011723900111.

Mourre, G., Isbasoiu, G. M., Paternoster, D. and Salto, M. (2013) The Cyclically-adjusted Budget Balance Used in the EU Fiscal Framework: An Update. European Economy Economic Papers No. 478. Brussels: European Commission.

Rosati D. K. (2013) "Konsolidacja fiskalna a kryzys zadłużenia w strefie euro" [Fiscal consolidation and debt crisis in euro area] in L. Oręziak, D. K. Rosati (eds) Kryzys finansów publicznych. Przyczyny, mechanizm, drogi wyjścia [The public finance crisis - causes, mechanism and the way out]. Warszawa: Oficyna Wydawnicza Uczelni Łazarskiego, pp. 11-37.

Rzońca, A. (2008) Paraliżujący deficit [Paralysing deficit]. Zeszyty FOR 1. Warszawa: Forum Obywatelskiego Rozwoju.

Skidelsky, R. (2012) Keynes. Powrót mistrza [Keynes. Return of the master]. Warszawa: Wydawnictwo Krytyki Politycznej.

Smith, A. (1954) Badania nad natura i przyczynami bogactwa narodów [An inquiry into the nature and causes of the wealth of nations], vol. 2. Warszawa: Państwowe Wydawnictwo Naukowe.

Wernik, A. (2011) Finanse publiczne [Public finance]. Warszawa: PWE.

\section{Abstract}

\section{Przywracanie równowagi finansów publicznych w Europie w świetle paktu fiskalnego}

Celem artykułu jest ocena stopnia, w jakim państwa członkowskie osiągnęły średniookresowe cele budżetowe (MTO) oraz punkt odniesienia (benchmark) w zakresie redukcji zadłużenia publicznego w świetle postanowień paktu fiskalnego, oraz określenie zagrożeń związanych z tym procesem. Na podstawie analizy statystycznej oraz badań literaturowych wykazano, że mniej niż połowa państw członkowskich zdołała spełnić 
wymagania narzucone przez pakt fiskalny. Wynik przeprowadzonej analizy wskazuje, że wpływ konsolidacji fiskalnej na wzrost gospodarczy jest postrzegany jako jeden z głównych powodów tego stanu rzeczy.

Autor uważa, że wymogi paktu fiskalnego są właściwym krokiem w kierunku zakotwiczenia dyscypliny budżetowej w Europie, i stwierdza, że w przypadku ścisłego wdrożenia i egzekwowania przepisów paktu powinien on wzmacniać istniejące ramy zarządzania finansami publicznymi i przyczyniać się do zwiększenia ich wiarygodności w przyszłości, co znacznie zmniejszy ryzyko wystąpienia kolejnego kryzysu zadłużenia suwerennego.

Słowa kluczowe: średniookresowy cel budżetowy, wskaźnik długu publicznego do PKB, konsolidacja fiskalna, pakt stabilności i wzrostu, pakt fiskalny. 